\title{
脱脂乾燥鵎皮の経口掑取による皮膚状態改善効果
}

\author{
川村 純 ${ }^{1,2}$, 琴浦 聡 $^{1}$, 奥山孝子 ${ }^{1}$, 古本真理 ${ }^{1}$, 府中英孝 ${ }^{1 *}$, \\ 三明清隆 ${ }^{1}$, 杉山雅昭 ${ }^{1}$ ，大西正男 ${ }^{2.3}$ \\ ${ }^{1}$ 丸大食品株式会社中央研究所 \\ 2 岩手大学大学院連合農学研究科 \\ 3 帯広畜産大学食品科学研究部門
}

\section{Effect of Oral Administration of Defatted Chicken Skin Powder on Dry Skin in Humans}

\author{
Jun Kawamura ${ }^{1.2}$, Satoshi Kotoura', Takako Okuyama', Mari Furumoto ${ }^{1}$, Hidetaka Fuchuu ${ }^{1 *}$, \\ Kiyotaka Miake', Masaaki Sugiyama ${ }^{1}$ and Masao Ohnishi ${ }^{2.3}$ \\ ${ }^{1}$ Central research institute, Marudai Food Co., Ltd, 21-3 Midori-cho, Takatsuki, Osaka 569-8577 \\ ${ }^{2}$ The United Graduate School of Agricultural Science, Iwate University, 3-18-8, Ueda, Morioka, Iwate 020-8550 \\ ${ }^{3}$ Department of Food Science, Obihiro University of Agriculture and \\ Veterinary Medicine, Inada-cho, Obihiro, Hokkaido 080-8555
}

\begin{abstract}
We investigated the effects of defatted-dried chicken skin powder (DCS) containing sphingomyelin (SM) on human facial skin conditions. A placebo-controlled, double-blind 12-week study of DCS (1 g/day ; SM2 mg/day) was conducted on 36 female volunteers who tend to have dry skin. In the DCS group, the moisture of the stratum corneum of cheek tended to increase after 12 weeks. In the subjects whose moisture of cheek was less than 35 arbitrary unit, the DCS group was significantly higher than the placebo group. After 12 weeks, skin elasticity showed significantly increase in the DCS group compared with $0 \mathrm{w}$. These results indicate that the ingestion of DCS improves dry facial skin.

(Received Nov. 15, 2012; Accepted Jan. 28, 2013)
\end{abstract}

Keywords : defatted chicken skin powder, sphingomyelin, skin moisture content, skin elasticity

キーワード : 脱脂乾燥鶏皮, スフィンゴミエリン, 皮膚水分量, 皮膚弾力性

鶏舎単位で全群更新方式が採用されて以来, 産卵率の低

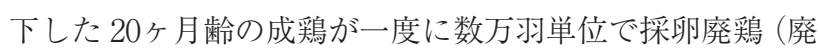
鶏）となる1! 廃鶏の肉としての利用は減少傾向にあり，平 成 22 年における食鳥処理量は肉用若鶏が 183 万トンで全 体の $90 \%$ 以上を占めるのに対して, 廃鶏は 15 万 8 千トン と全体の約 $8 \%$ に留まっている 資源として有効に利用されていないのが現状であり，その 有効利用方法が求められている. Yunoki らは廃䳕の表皮 部がスフィンゴ脂質の一種であるスフィンゴミエリン (SM）の供給源として有用であることを報告している2). 我々はこの知見に基づいて廃鶏の有効利用法について研究 を行っており，これまでに廃䳕表皮を効率的に脱脂し, SM を濃縮した脱脂乾燥鵎皮粉末 (defatted-dried chicken skin, DCS）を開発している ${ }^{3)}$ SM はスフィンゴイド塩基と脂肪

\footnotetext{
${ }^{1} \mathbf{T} 569-8577$ 大阪府高槻市緑町 21-3

2 T020-8550 岩手県盛岡市上田 3-18-8

${ }^{3} \mathbf{T} 080-8555$ 北海道帯広市稲田町西 2 線 11

*連絡先 (Corresponding author), fuchuu_hidetaka@marudai.co.jp
}

酸からなるセラミドにリン酸コリンが結合した構造を有し ており, 高等動物の細胞膜, 神経組織, ヒトの表皮にも存 在が認められている4).

ヒトの皮膚は表皮, 真皮および皮下組織に分けられるが, 表皮の最上部である角質層の細胞間脂質の約 $50 \%$ を占め ているセラミドは水分保持や異物侵入防止など皮膚の維持 に重要な役割を果たしている5 ${ }^{56}$. 角質層のセラミドは，角 質層の下に存在する顆粒層に蓄積されている SM とグルコ シルセラミド (GlcCer) がスフィンゴミエリナーゼ等によ り加水分解されることによって生成することから, SM は セラミドの前駆体として皮膚の保湿機能に重要な役割を果 たしていると考えられている778.

皮膚保湿効果を訴求した商品に利用されている「セラミ ド」素材の大部分は米, こんにゃく, 小麦, トウモロコシ 等の植物性原料由来の GlcCer である。これまでに GlcCer の経口摂取による皮膚への効果が検討されており, 皮膚水 分量の増加や経皮水分蒸散量の低下作用による皮膚保湿能 の改善効果が認められている 
表 1 DCS の栄養成分値

\begin{tabular}{lc}
\hline \hline & 含有率 $(\%)$ \\
\hline 水分 & 2.6 \\
タンパク質 & 63.1 \\
脂質 & 33.4 \\
灰分 & 0.9 \\
コラーゲン & 39.7 \\
スフィンゴミエリン & 0.2 \\
\hline
\end{tabular}

表 2 試験食品の栄養成分値

\begin{tabular}{lcc}
\hline \hline & プラセボ湶取群 & DCS 㧺取群 \\
\hline エネルギー $(\mathrm{kcal})$ & 3.880 & 4.050 \\
タンパク質 $(\mathrm{g})$ & 0.002 & 0.095 \\
脂質 $(\mathrm{g})$ & 0.056 & 0.084 \\
炭水化物 $(\mathrm{g})$ & 0.843 & 0.729 \\
灰分 $(\mathrm{g})$ & 0.040 & 0.041 \\
スフィンゴミエリン (mg) & 0 & 0.250 \\
コラーゲン $(\mathrm{g})$ & 0 & 0.038 \\
\hline
\end{tabular}

錠剤一粒（1g）あたりの成分值

「セラミド」含有素材は牛乳由来の SM が上市されており， GlcCer と同様に経口摂取によって皮膚保湿機能が改善す る報告例がある ${ }^{10)}$. しかし，牛乳由来の SM では脂肪酸と スフィンゴイド塩基の構造が廃䳕表皮由来の SM と異なっ ており ${ }^{11)}$, 皮膚に対して同様の効果を発揮するかは不明で ある。そこで，我々は廃䳕表皮由来の SM を含む DCS を 用いてヒト経口摂取試験を実施し，その肌状態に及ぼす影 響について検証することで廃鶏表皮の食品素材としての有 効性を検討した.

\section{実 験 方 法}

\section{1. 被験者}

対象となる被験者は肌の乾燥を自覚している 31 歳から 59 歳の健康な成人女性を対象として募集し, 㚘頁の皮膚水分量 が 50 arbitrary unit（a.u.）以下，且つ前腕の水分量が 35 a.u. 以下である 38 名が被験者としてエントリーされた。なお， 本試験では測定機器メーカーである Courage+ Khazaka Electronic Gmbh 社の参考資料に基づき㚘頁の水分量 50 a.u. 未満を「大変乾燥」，50～60 a.u.を「乾燥」とした，本研究 ではこの 38 名を無作為に二群（プラセボ摂取群，DCS 摂 取群）に割り付け，群間で煩の皮膚水分量，平均年齢に有 意差がないことを確認した。試験期間中に自己都合による 脱落や使用している化粧品の変更が確認された 2 名を解析 対象から除外して, 最終的に解析の対象となった被験者数 は36名であった，本試験の実施に際しては常に被験者の 人権保護に配慮し,ヘルシンキ宣言の主旨に従い, 疫学研究 に関する倫理指針（文部科学省・厚生労働省告示）を遵守 した。な㧍，本試験は医療法人社団快晴会田奈整形外科 .
表 3 被験者背景

\begin{tabular}{lcc}
\hline \hline & プラセボ摂取群 & DCS 摂取群 \\
\hline 被験者数 & 19 & 17 \\
年齢 & $38.5 \pm 5.4$ & $38.2 \pm 4.5$ \\
皮膚水分量 & $34.7 \pm 6.7$ & $36.0 \pm 8.8$ \\
経皮水分蒸散量 & $16.7 \pm 4.8$ & $14.7 \pm 3.8$ \\
皮膚弾力性 $(\mathrm{R} 7)$ & $0.2 \pm 0.0$ & $0.3 \pm 0.0$ \\
\hline
\end{tabular}

外科倫理審査委員会の審査を受け，皮膚の評価測定は医療 法人社団快晴会新横浜篠原口整形外科・皮膚科新横浜入キ ンラボセンター(神奈川県横浜市) の協力を得て実施した。

\section{2. 脱脂乾燥鷄皮粉末の調製}

廃鵴皮は農事組合法人エヌチキン（鹿児島県南九州市） より入手し, $4.8 \mathrm{~mm}$ のミンチにした後, 加熱処理による脱 脂を行った。加熱にはアクアガス加熱装置 hi-LOHS-R（夕 イヨー製作所, 北海道北斗市) を用いて, 装置内温度 $105^{\circ} \mathrm{C}$, 15 分間の条件下で加熱した ${ }^{3}$. 冷却後, 凍結乾燥と粉砕工 程を経て DCS を得た. DCS の栄養成分值を表 1 に示す. な㧍，上述の方法で生鶏皮ミンチ $100 \mathrm{~kg}$ から DCS $12.5 \mathrm{~kg}$ を得た。

\section{3. 供試食品}

供試食品には 1 粒あたり DCS が $125 \mathrm{mg}$ 含有するよう に配合した錠剤を調製した。プラセボ食品はDCS の代替 として市販のコーンスターチを配合した錠剤を用いた。錠 剤は原料を混合した後, 直径 $1.5 \mathrm{~cm}, 1 \mathrm{~g}$ となるように打錠 したものを用いた，試験食品の栄養成分值を表 2 に示し た。供試食品とプラセボ食品は外見上識別が不可能であ り，試験期間を通して各被験者に成分を開示しなかった。

\section{4. 試験デザイン}

試験実施期間は 2011 年 12 月から 2012 年 3 月の 12 週間 とした。試験方法はプラセボを対照とした二重盲検並行群 間比較試験を採用した。試験群は供試食品を摂取するDCS 摂取群（DCS 摂取量 $1 \mathrm{~g} /$ 日， SM として $2 \mathrm{mg} /$ 日）とプラ セボ食品を摂取するプラセボ損取群の二群を設定した。

割付責任者は乱数表に基づいて被験者の無作為割付を 行った後，割付表を封緘し，試験終了時まで保管した。な お，割付表の開封はすべての試験終了後に行った。試験期 間中は被験者に対して下記の注意事項を遵守させた．

(1) 健康食品の摂取を中止する。また, 肌改善効果を標榜 した食品を通常以上に摂取しない

(2) セラミド素剂を含有した化粧品を使用しない.

(3) 極端に日焼けをする行為を行わない.

(4) 使用する化粧品を変更しない.

上記の注意事項を㛜守させるとともに試験食品の摂取状 況や体調, 自覚症状, 食事内容等を毎日日誌に記録させた.

\section{5. 検査方法}

（1）測定条件

皮膚水分量，経皮水分蒸散量㧍よび皮膚弾力性の測定は 
摂取開始前, 摂取 4 週間後, 摂取 8 週間後および摂取 12 週 間後に実施した。測定時の条件を同一に保つため，被験者 は指定された方法で洗顔を行った後, 室温 $21 \pm 1^{\circ} \mathrm{C}$, 湿度 $50 \pm 5 \%$ に設定した室内で 40 分間安静状態にした後, 各項 目を測定した。皮膚水分量，経皮水分蒸散量および皮膚弾 力性は左煩（目尻から扔ろした鉛直線と鼻の頂点を通る水 平な線の交点）を測定部位とした。

(2) 測定方法

i ）皮膚水分量

皮膚水分量は Corneometer CM850（Courage+Khazaka Electronic Gmbh 社) を用いて测定した。測定部位を 8 回 測定し, 最大值と最小值を棄却した平均值を評価に用いた。

ii）経表皮水分蒸散量

経表皮水分蒸散量（transepidermal water loss : TEWL) は Tewameter TM300（Courage + Khazaka Electronic Gmbh 社）を用いて測定した。測定部位を 8 回測定し, 最大值と 最小值を充却した平均值を評価に用いた。

iii）皮膚弾力性（R7）

皮膚弾力性評価には Cutometer MPA50（Courage+ Khazaka Electronic Gmbh 社) を用いた，測定部位の皮膚 表面を院圧でプローブ開口部に引き込み，開口部に引き込 まれた皮膚長をプリズムを用いて測定した。吸引・解放す ることによる伸展・退縮後の皮膚の高さの復元率（R7）を 皮膚弾力性指標とした

iv）肌状態のアンケート調査

各被験者の皮膚の自覚症状として，摂取 4 週間後，摂取 8 週間後, 摂取 12 週間後に顔の肌状態に関するアンケート 調査を実施した。調査項目は「乾燥」，「しっとり感」「柔 らかさ」,「透明感」,「ハリと弾力」,「ふっくら感」,「キメ の粗さ」,「毛穴の目立ち」，「たるみ」，「しわ」，「シミ」お よび「化粧のり」とした。同時に体の肌状態に関する「乾 燥」,「赤み」,「かゆみ」および「肌の調子」についてアン
ケート調査も実施した。検査時の肌の評価は各項目を 5 段 階（5：大変よい，4：よい，3：どちらでもない， 4 : 悪い, 5 ：大変悪い）で自己評価させた．

\section{6. 統計処理}

皮膚水分量，経皮水分蒸散量，皮膚弾力性指標における 有意性の評価は，群間比較に対応のない $\mathrm{t}$ 検定，摂取前後 の比較は対応のある $\mathrm{t}$ 検定により行った。アンケート調査 結果の二群比較は Mann-Whitney のU 検定を用いて評価 した。両側検定で有意水準 $5 \%$ 未満を有意性ありと評価し た

\section{実 験 結 果}

\section{1. 被験者の背景因子}

摂取試験開始前に, 被験者 36 名の年齢, 皮膚水分量, 経 皮水分蒸散量および肌弾力性指標を測定したところ，群間 での有意な差は認められなかった（表 3 ).

\section{2. 皮膚水分量への影響}

皮膚水分量の初期值を $100 \%$ として各測定時の変化率を 算出した結果を図 1 に示した。摂取 12 週間後における皮 膚水分量の変化率は，プラセボ摂取群の $113 \%$ に対して DCS 摂取群では $121 \%$ であったが群間の有意差は認めら れなかった（図1a）。さらに，肌の乾燥が重度な被験者に 対する試験食品の効果を調査するため, 解析対象者の皮膚 水分量の平均值である 35 a.u.を境界とし，試験開始直後 $(0$ 週）の検查において皮膚水分量が 35 a.u.未満の被験者に対 して層別解析を行った。その結果，摂取 12 週間後におけ る皮膚水分量の変化率はプラセボ摂取群では $122 \%$ であっ たが，DCS 摂取群では $141 \%$ であり，有意（ $p<0.05 ） に$ 高 かった（図 $1 \mathrm{~b}$ )。また, 被験者の平均年齢 38 歳を境界とし て層別解析を行った結果, 38 歳以上の被験者において摂取 前と比べ摂取 12 週間後で改善が認められた $(p<0.05)$ 。し かし，この場合は両群間で有意差はなかった。
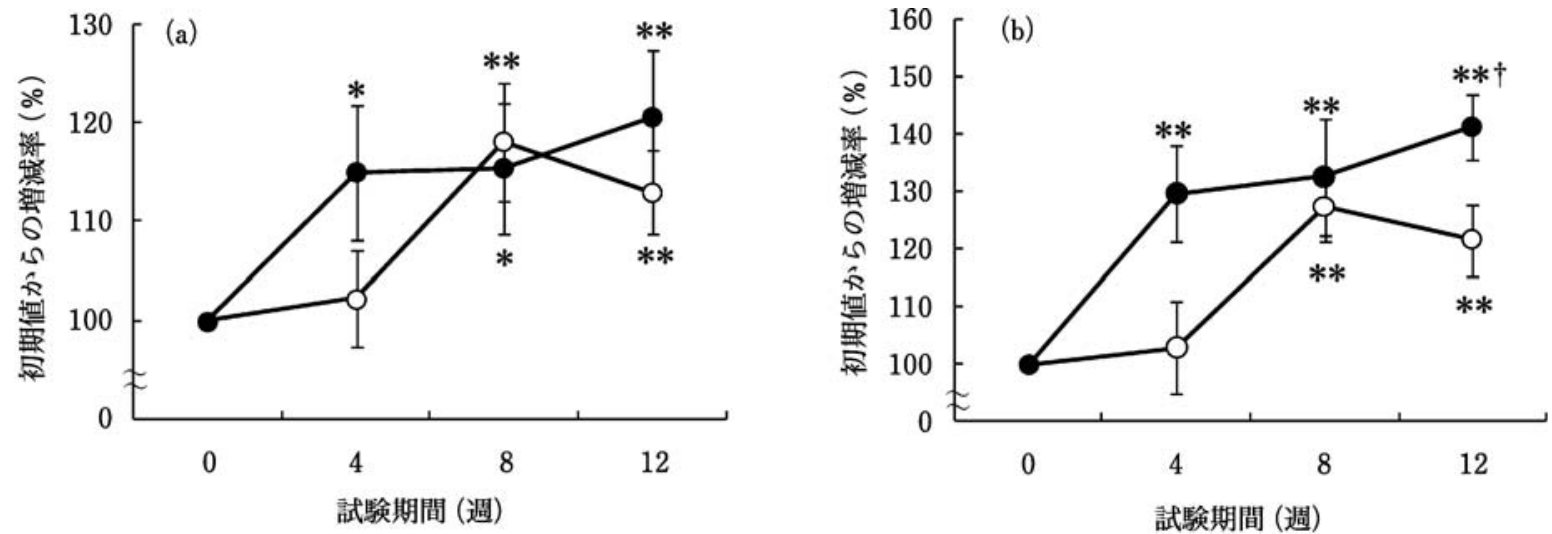

図 1 皮膚水分量変化率に及ぼす DCS の影響

（a）全被験者 $(n=36)$, (b) 皮膚水分量 35 a.u. 未満の被験者 $(n=15)$. $\bigcirc$, プラセボ摂取群;

DCS 摂取群 $p<0.05,{ }^{* *} p<0.01$ (同一群の摂取前後での比較), $\dagger p<0.05$ (プラセボとの比較). 増減率 $=4,8,12$ 週後の 測定值 $/ 0$ 週の測定值 $\times 100$ で算出 


\section{3. 経皮水分蒸散量への影響}

経皮水分蒸散量の初期值を $100 \%$ として各測定時の変化 率を算出した結果を図 2 に示した。両群において摂取前と 比較して減少する傾向が認められたが（プラセボ摂取群； $85 \%$ ，DCS 摂取群； $88 \%$ )，摂取 12 週間後においてもプラ セボ摂取群と DCS 摂取群の間に有意差は認められなかっ た。 また，水分量と同様に解析対象者の水分蒸散量と年齢 の平均值を境界として層別解析を行った結果，群間に差は 認められなかった（データ非掲載）.

\section{4. 皮膚弾力性への影響}

皮膚弾力性指標 R7 の初期值を $100 \%$ として各測定時の 変化率を算出した結果を図 3 に示した。摂取 12 週間後の R7 の変化率はプラセボ摂取群では $105 \%$ であるのに対し て，DCS 摂取群では $108 \%$ と摂取前よりも有意 $(p<0.05)$ に増加した（図 3a).解析対象者の測定值を境界として層別 解析を行った結果，群間差は認められなかった.年齢による 層別解析を行った結果, 38 歳以上の被験者では摂取 12 週

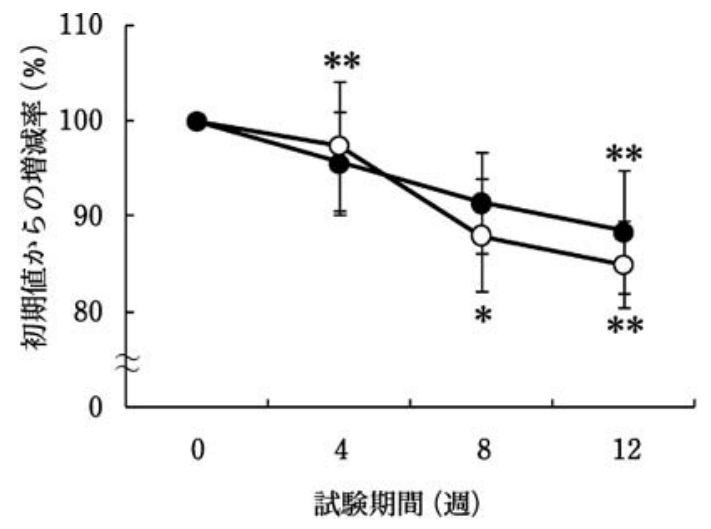

図 2 経皮水分蒸散量変化率に及ぼす DCS の影響 全被験者 $(n=36)$ 。 ○, プラセボ摂取群；○, DCS 摂取群。 ${ }^{*} p<0.05,{ }^{* *} p<0.01$ (同一群の摂取前後での比較). 増減率 $=4,8,12$ 週後の測定值 $/ 0$ 週の測定值 $\times 100$ で算出
間後のプラセボ摂取群の変化率が $98 \%$ であったのに対し て DCS 摂取群では $110 \%$ であり,改善傾向が認められた( $=0.056$ ) (図 $3 \mathrm{~b}$ ).

\section{5. 被験者肌状態アンケートの結果}

被験者の肌状態に対する自覚症状はアンケートを用いて 評価した。12週間後において，「総合的な満足度」および 「しみ」等の計 5 項目のスコアが DCS 摂取群においてのみ 増加し, 摂取前と比較して有意 $(p<0.05)$ な改善が認めら れた（表 4)。一方，皮膚水分量 35 a.u.未満の被験者のアン ケート結果を層別解析した結果, DCS 摂取群においてのみ 「総合的な満足度」,「肌の乾燥」,「肌のかゆみ」など計 13 項目のスコアが上昇しており，摂取前と比べて有意差が認 められた $(p<0.05)$. 年齢による層別解析の結果では, DCSの摂取による改善は認められなかった。

\section{6. 摄取に伴う有害事象}

試験食品を摂取した 38 名のうち 17 名に 27 件の自他覚 症状が発現した。そのうち DCS 摂取群には 19 名中 10 名 （発現頻度 $52.6 \% ） に 16$ 件発現し，プラセボ摂取群には 19 名中 7 名（発現頻度 $36.8 \%$ ）に 11 件発現した。 DCS 摂取 群では腹痛 3 件, 感冒症状 8 件, 腰痛 2 件, 胃腸痛 1 件, 頭 痛 1 件，インフルエンザ 1 件であった。プラセボ摂取群で は腹痛 1 件, 感冒症状 5 件, 腰痛 2 件, 肩こり 1 件, 湿疹 1 件，かぶれ 1 件であった。これらの症状の程度はすべて軽 度であり，いずれも試験食品摂取期間中に消失した。すべ ての有害事象について，試験責任医師が試験食品との関連 はなしと判定した。

\section{考察}

脱脂乾燥䳕皮粉末（DCS）を含有する錠剤（DCS 摂取量 $1 \mathrm{~g} /$ 日， SM 換算 $2 \mathrm{mg} /$ 日）の経口摂取がヒトの肌状態に及 ぼす影響を検証するため, 12 週間の二重盲検並行群間試験 を行った。全被験者を対象として解析したところ, DCS 摂
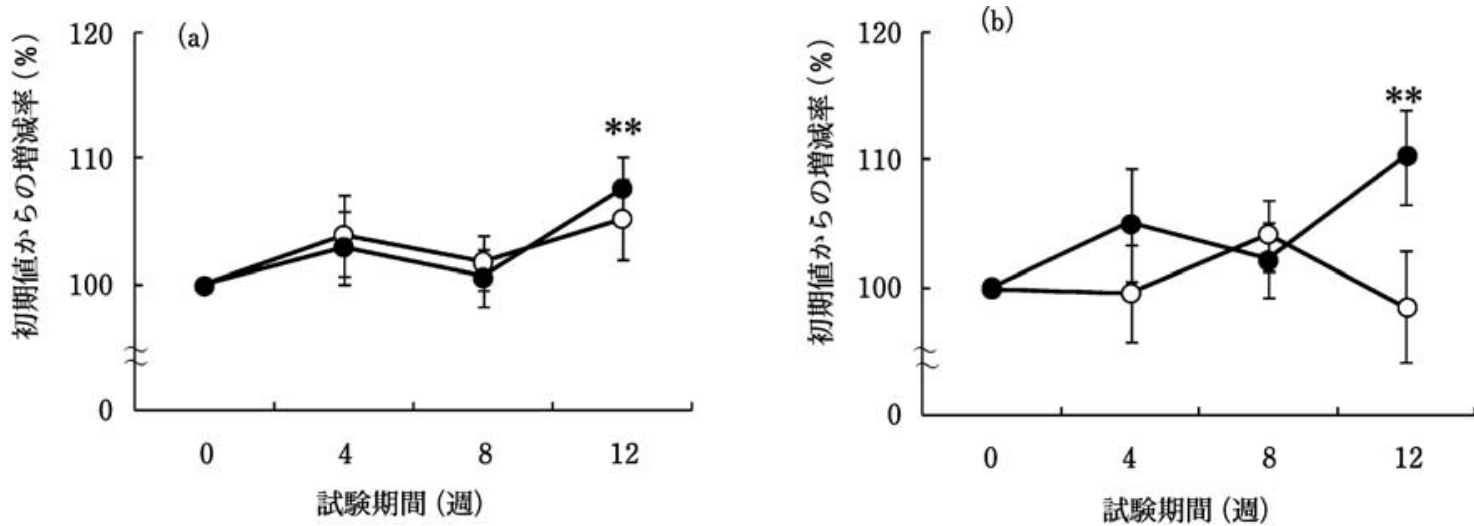

図 3 皮膚弾力性の変化率に及ぼす DCS の影響

（a）全被験者 $(n=36) ，(b) 38$ 歳以上の被験者 $(n=20)$ ， ○，プラセボ摂取群 ${ }^{*} p<0.05,{ }^{* *} p<0.01$ (同一群の摂取前後での比較).

増減率 $=4,8,12$ 週後の測定值 $/ 0$ 週の測定值 $\times 100$ で算出. 
表 4 皮膚状態アンケート結果

\begin{tabular}{|c|c|c|c|c|c|c|c|c|}
\hline & \multicolumn{4}{|c|}{ 全被験者 } & \multicolumn{4}{|c|}{ 皮膚水分量 35a.u.未満の被験者 } \\
\hline & \multicolumn{2}{|c|}{ プラセボ摂取群 } & \multicolumn{2}{|c|}{ DCS 摂取群 } & \multicolumn{2}{|c|}{ プラセボ摂取群 } & \multicolumn{2}{|c|}{ DCS 摂取群 } \\
\hline & 0 週 & 12 週 & 0 週 & 12 週 & 0 週 & 12 週 & 0 週 & 12 週 \\
\hline \multicolumn{9}{|l|}{ 顔 } \\
\hline 総合的な満足度 & $1.9 \pm 0.5$ & $2.2 \pm 0.7$ & $1.8 \pm 0.4$ & $2.4 \pm 0.6^{*}$ & $2.0 \pm 0.0$ & $2.1 \pm 1.0$ & $1.6 \pm 0.5$ & $2.6 \pm 0.5^{*}$ \\
\hline 乾燥 & $1.5 \pm 0.5$ & $2.0 \pm 0.7^{*}$ & $1.5 \pm 0.5$ & $2.3 \pm 0.8^{*}$ & $1.8 \pm 0.5$ & $2.0 \pm 0.9$ & $1.6 \pm 0.5$ & $2.4 \pm 0.8^{*}$ \\
\hline 肌のしっとり感 & $1.9 \pm 0.5$ & $2.4 \pm 0.7^{* *}$ & $1.7 \pm 0.5$ & $2.4 \pm 0.7^{* *}$ & $1.6 \pm 0.5$ & $2.4 \pm 0.7^{*}$ & $1.7 \pm 0.5$ & $2.6 \pm 0.8^{*}$ \\
\hline 肌やわらかさ & $2.4 \pm 0.7$ & $2.6 \pm 0.9$ & $2.4 \pm 0.6$ & $2.6 \pm 0.6$ & $2.5 \pm 0.9$ & $2.1 \pm 0.8$ & $2.3 \pm 0.5$ & $2.7 \pm 0.8$ \\
\hline 肌の透明感 & $1.9 \pm 0.8$ & $2.1 \pm 0.6$ & $1.9 \pm 0.6$ & $2.4 \pm 0.6^{*}$ & $1.6 \pm 0.7$ & $1.9 \pm 0.6$ & $2.0 \pm 0.8$ & $2.6 \pm 0.5^{*}$ \\
\hline 肌のハリや弾力 & $1.8 \pm 0.7$ & $2.3 \pm 0.9^{*}$ & $1.8 \pm 0.6$ & $2.3 \pm 0.8^{* *}$ & $1.8 \pm 0.9$ & $2.3 \pm 0.9$ & $1.7 \pm 0.8$ & $2.4 \pm 1.0^{*}$ \\
\hline 肌のふっくら感 & $1.9 \pm 0.6$ & $2.6 \pm 0.8^{* *}$ & $2.1 \pm 0.7$ & $2.6 \pm 0.6^{*}$ & $1.9 \pm 0.8$ & $2.5 \pm 1.1$ & $1.9 \pm 0.7$ & $2.9 \pm 0.7^{*}$ \\
\hline 肌のキメの粗さ & $2.1 \pm 1.0$ & $2.3 \pm 1.0$ & $1.7 \pm 0.5$ & $2.1 \pm 0.6^{* *}$ & $2.0 \pm 0.9$ & $1.8 \pm 0.7$ & $1.6 \pm 0.5$ & $2.1 \pm 0.7^{*}$ \\
\hline 毛穴の目立ち & $1.6 \pm 0.8$ & $2.0 \pm 1.0^{*}$ & $1.4 \pm 0.5$ & $1.9 \pm 0.5^{*}$ & $1.3 \pm 0.5$ & $1.8 \pm 0.9$ & $1.1 \pm 0.4$ & $2.0 \pm 0.6^{*}$ \\
\hline 肌のたるみ & $1.5 \pm 0.6$ & $2.1 \pm 0.9^{* *}$ & $1.6 \pm 0.7$ & $1.9 \pm 0.9$ & $1.4 \pm 0.5$ & $2.0 \pm 0.8$ & $1.6 \pm 0.5$ & $2.4 \pm 1.0^{*}$ \\
\hline しわ & $1.5 \pm 0.6$ & $1.9 \pm 0.7^{*}$ & $2.1 \pm 0.9$ & $2.5 \pm 0.9^{*}$ & $1.5 \pm 0.5$ & $2.0 \pm 0.5$ & $2.1 \pm 0.9$ & $2.9 \pm 0.9$ \\
\hline しみ & $1.6 \pm 0.7$ & $1.8 \pm 0.7$ & $1.6 \pm 0.8$ & $1.9 \pm 0.9^{*}$ & $1.8 \pm 0.9$ & $1.9 \pm 1.0$ & $1.6 \pm 0.8$ & $2.1 \pm 0.9^{*}$ \\
\hline 化粧ノリ & $2.1 \pm 0.6$ & $2.4 \pm 0.8^{*}$ & $2.1 \pm 0.8$ & $2.6 \pm 0.8^{*}$ & $2.0 \pm 0.5$ & $2.1 \pm 0.8$ & $1.6 \pm 0.5$ & $2.7 \pm 1.0^{*}$ \\
\hline \multicolumn{9}{|l|}{ 体 } \\
\hline 肌の乾燥 & $1.7 \pm 0.6$ & $2.2 \pm 0.9$ & $1.7 \pm 0.5$ & $2.2 \pm 0.7^{*}$ & $1.9 \pm 0.6$ & $1.9 \pm 1.0$ & $1.7 \pm 0.5$ & $2.4 \pm 0.8$ \\
\hline 肌の赤み & $2.9 \pm 1.2$ & $3.3 \pm 1.3$ & $3.2 \pm 0.9$ & $3.4 \pm 1.1$ & $3.0 \pm 1.1$ & $3.4 \pm 1.1$ & $3.1 \pm 0.7$ & $3.7 \pm 1.0$ \\
\hline 肌のかゆみ & $2.6 \pm 1.0$ & $3.4 \pm 1.2^{*}$ & $2.6 \pm 0.9$ & $3.4 \pm 0.8^{* *}$ & $3.0 \pm 1.2$ & $3.4 \pm 1.2$ & $3.0 \pm 0.8$ & $3.7 \pm 0.8^{*}$ \\
\hline 肌の調子 & $2.3 \pm 0.7$ & $2.8 \pm 0.9^{*}$ & $2.3 \pm 0.6$ & $3.1 \pm 0.7^{* *}$ & $2.4 \pm 0.7$ & $2.6 \pm 0.9$ & $1.9 \pm 0.4$ & $3.0 \pm 0.6^{*}$ \\
\hline 合計スコア & $33.4 \pm 6.00$ & $40.4 \pm 10.2^{* *}$ & $33.6 \pm 5.4$ & $42.1 \pm 6.9^{* *}$ & $33.3 \pm 7.1$ & $38.0 \pm 11.5$ & $32.0 \pm 6.2$ & $45.3 \pm 6.8^{*}$ \\
\hline
\end{tabular}

平均值士標準偏差，全被験者 $(n=36)$, 皮膚水分量 35 a.u.未満の被験者 $(n=15)$.

${ }^{*} p<0.05,{ }^{* *} p<0.01$ (同一群の摂取前後での比較). 表中の数值は各項目を 5 段階で自己評価した平均值（5 点：大変よい，4点：よ い, 3 点：どちらでもない, 2 点：悪い, 1 点：大変悪い).

取群では摂取前と比較して皮膚水分量は改善を示した。し かし，プラセボ摂取群においても DCS 摂取群と同様の傾 向が認められ, 群間での有意差は認められなかった。一方, 被験者の中から左㚘頁の皮膚水分量が 35 a.u. 未満の被験者 15 名を対象に層別解析を行ったところ，摂取 12 週間後の 皮膚水分量において DCS 摂取群はプラセボ摂取群と比較 して有意な増加が認められた $(p<0.05)$ 。さらに，皮膚水 分量が 35 a.u.未満の被験者においてはアンケート調査にお いて「顔の乾燥」項目が DCS 摂取群において改善した。 38 歳以上の被験者における解析結果では, DCS 群において試 験前後の水分量が有意に改善していたが, 群間差は認めら れず, 自覚症状においても顕著な改善は認められなかった。 以上の結果から, DCS の摂取は皮膚の乾燥が重度な人の皮 虐水分量を改善し, 顔の乾燥状態を改善することが示唆さ れた。経皮水分蒸散量は DCS 摂取群で減少傾向を示した が，プラセボ摂取群においても同様の傾向が認められ， DCSの摂取による明確な改善効果は認められなかった。

ヒトの肌の水分保持には角質層が重要な役割を担ってお り，角層は表皮角化細胞が分化した角層細胞とその細胞間 に充満する細胞間脂質から構成される。細胞間脂質はコレ ステロール, 脂肪酸，セラミドを主成分とし，ラメラ構造 を形成することで細胞間に水分を保持し，皮膚の保湿に寄
与している ${ }^{1213)}$ ）近年では美容を目的とした機能性食品素 材として植物由来の GlcCer や牛乳由来の SM を主成分と した「セラミド」素材が上市されており，これら素材の経 口摂取により肌機能が改善した報告例がある。春田らは, 牛乳由来 SM をヒトに対して 1 日あたり $22 \mathrm{mg}$ の投与量 で 6 週間経口投与したところ，皮膚の水分量が改善したこ とを報告している ${ }^{10)}$. 本試験にて被験者に供試した DCS は 1 日あたり $1 \mathrm{~g}$ であり，この中に含まれる $\mathrm{SM}$ 量は $2 \mathrm{mg}$ と 上記の知見よりも少ないにもかかわらず皮膚水分量の増加 が認められた。牛乳中に含まれる SM は鶏皮中の SM とス フィンゴイド塩基の組成が異なっていることが報告されて いることから ${ }^{2) 111}$, 塩基組成の違いが生体内での利用性に影 響を及ぼしている可能性が考えられた．SM の経口摂取に よる肌への作用メカニズムについては，皮膚におけるセラ ミド合成の促進 ${ }^{14)}$ などが報告されているが，未だ統一した 見解が得られていないのが実情である.

経口摂取されたスフィンゴ脂質は消化管内で酵素作用に よりスフィンゴイド塩基と脂肪酸に分解された後，一部が 吸収されることが知られているが15), 動物性と植物性のス フィンゴ脂質では吸収性が異なると考えられている。動物 の主要なスフィンゴ脂質はSM であり，主要なスフィンゴ イド塩基は 4-sphingenine である。一方，植物の主要なス 
フィンゴ脂質は GlcCer であり，スフィンゴイド塩基は 8sphingenine や 4,8-sphingadienine 等の 9 種類が確認され ている ${ }^{16) 177}$. Sugawara らは動物由来と植物由来のスフィンゴ イド塩基は腸管細胞への取り込み能が異なっており, 動物 由来と比べ植物由来のスフィンゴイド塩基は小腸粘膜細胞 への取り込み量が少ないことを示している ${ }^{18)}$. Yunokiらは 皮部の SM の主要なスフィンゴイド塩基は 4-Sphingenine であり，哺乳動物と類似した構造を有していることを報告 している2!.これらのことから, 本試験において使用された DCS 中の SM は既存の植物由来 GlcCer より吸収性に優れ ていることが推測された.

皮膚弾力性指標 R7 の測定結果では摂取前と比較して DCS 摂取群のみで改善が認められた。さらに 38 歳以上の 被験者に対して層別解析を行ったところ, 摂取 12 週間後 の R7 はプラセボ摂取群と比較して DCS 摂取群において 顕著な改善傾向が認められた。 $\mathrm{R} 7$ は真皮の弾性繊維の変 化や弾性繊維ネットワークの変化と関係している值であ り，加齢に伴って減少することが報告されている ${ }^{1920)}$. 本試 験において 38 歳以上の DCS 摂取群の被験者において皮膚 弾力性の増加が顕著であったことから, DCS は加齢に伴う 皮膚弾力の低下を抑制もしくは改善する可能性が考えられ た。

試験食品に使用したDCS は, SM 以外のリン脂質やコ ラーゲンなどのタンパク質も含んでいる。コラーゲンは真 皮の主要な構成成分であり, 皮膚のはり・弾力・硬さに関 わっている ${ }^{21}$. 近年, コラーゲン含有の健康食品は注目を 集めてきているが, これはコラーゲンを経口摂取すること で皮膚中のコラーゲン合成を促進する美容効果を期待する ところが大きいと考えられている。コラーゲン含有食品の ヒトによる経口摂取試験では, 皮膚弾力性の向上 ${ }^{22}$, 角質水 分量の増加が報告されている活 が，これらの報告例は抽出 したコラーゲンを酵素処理することで低分子化しており， 摂取量も 2.5〜 $10 \mathrm{~g}$ /日と本試験の DCS に由来するコラー ゲン量 $(300 \mathrm{mg} /$ 日) よりも多い. よって本試験において 認められた皮膚弾力性や皮膚水分量の増加はDCS 中のコ ラーゲンに由来するものとは考え難い. スフィンゴ脂質に おいて，ビート由来 GlcCer $1.8 \mathrm{mg}$ をヒトに対して 8 週間 経口摂取させることで㚘部皮膚の弾力性の改善 ${ }^{24)}$ が認めら れていることから, 本試験にて認められた皮膚弾力性の改 善はDCS 中に含まれる SM による効果である可能性が考 えられる。

これらの結果より, DCS は皮膚の乾燥が重度な人の皮膚 保湿性を改善させ, 加齢により低下した皮膚弾力性の改善 に寄与できる可能性がある。本試験の実施期間は 12 月か ら 3 月の低湿な気候条件の時期に実施しており, 一般的に は皮膚の乾燥感を訴える人が多い.このような時期に DCS を摂取することで肌状態の改善が期待できる。今後, 本試験において改善傾向が認められた項目に対してより詳
細に検討し, DCSの摂取効果がどのような作用機序で発現 するかを明確にする必要がある。

\section{要約}

廃鶏表皮を原料として脱脂乾燥鵎皮粉末（DCS）を調製 し，その摂取がヒトの肌に及ぼす影響を確認する目的でヒ トによる二重盲検並行群間試験を実施した。 その結果, DCS 摂取群において皮膚水分量の増加傾向が認められ, 特 に皮膚の乾燥が重度な被験者においてはプラセボ摂取群と 比較して有意に増加した。また, DCSの摂取後では皮膚弾 力性が摂取前と比較して有意に増加していた。本試験の結 果から, DCSの摂取は皮膚の乾燥が重度な人の皮膚保湿性 を改善させ, 加龄により低下した皮膚弾力性を改善する可 能性が示された。

\section{文献}

1）駒井 亨, 畜産の情報 国内編 平成 15 年 8 月号, No. 166 (農 畜産業振興事業団), pp. 4-9 (2003).

2) Yunoki, K., Kukino, O., Nadachi, Y., Fujino, T. and Ohnishi, M., Separation and determination of functional complex lipids from chicken skin. J. Am. Oil. Chem Soc., 85, 427-433 (2008).

3）府中英孝, 柚木恵太, 松山弘幸, 藤野武彦, 大西正男, 小玉 芳郎, 杉山雅昭, 親鶏由来の機能性リン脂質 : スフィンゴミ エリンの抗高脂血症及び抗高血糖効果, ブレインテクノ ニュース, 141, 13-19 (2010).

4）七ラミド研究会, 「セラミド一基礎と応用一」, (食品化学新 聞社, 東京) p. 6 (2011).

5) Elias, P. M., Epidermal lipids, barrier function, and desquamation. J. Invest. Dermatol, 80, 44-49 (1983).

6) Mizutani, Y., Mitsutake, S., Tsuji, K., Kihara, A. and Igarashi, Y., Ceramide biosynthesis in keratinocyte and its role in skin function. Biochemie., 91, 784-790 (2009).

7) Uchida,Y., Hara, M., Matsuyama, H., Yamamura, J., Tanaka, M., Aoe, S., Iwanaga, T. and Kawakami, H., Epidermal sphingomyelins are precursors selected stratum corneum ceramides. J. Lipid Res., 41, 2071-2082 (2000).

8) Hamanaka, S., Hara, M., Nishio, H., Otsuka, F., Suzuki, A and Uchida, Y., Human epidermal glucosylceramides are major precursors of stratum corneum ceramides. J. Invest. Dermatol, 119, 416-423 (2002).

9) Uchiyama, T., Nakano, Y., Ueda, O., Hiroshi, M., Nakashima, M., Noda, A., Ishizaki, C. and Mizoguchi, M., Oral intake of glucosylceramide improves relatively higher level of transepidermal loss in mice and healthy human subjects. $J$. Health Science, 54, 559-566 (2008).

10）春田裕子, 上田典子, 加藤 健, 过 秀一, 吉岡俊満, 皮膚 に対する牛乳由来スフィンゴミエリン高含有素材の臨床効 果, Milk Science, 58, 135-141 (2009).

11) Ramstedt, B., Leppimaki, P., Axberg, M. and Slotte, P., Analysis of natural and synthetic sphingomyelins using high-performance thin-layer chromatography. Eur. J. Biochem., 266, 9971002 (1999)

12) Man, M.M., Feingold, K.R., Thornfeidt, C.R. and Elias, P.M., Optimization of physiological lipid mixture for barrier repair. J. Invest. Dermatol., 106, 1096-1101 (1996).

13) Man, M.Q., Feingold, K.R. and Elias, P.M., Exogenous lipids influence permeability barrier recovery in acetone-treated 
murine skin. Arch. Dermatol., 129, 728-738 (1993).

14) Duan, J.J., Sugawara, T., Hirose, M., Aida, K., Sakai, S., Fujii, A. and Hirata, T., Dietary sphingolipids improve skin barrier function via the upregulation of ceramide synthases in the epidermis. Experimental Dermatology, 21, 448-452 (2012).

15) Duan, RD. and Nilsson, A., Metabolism of sphingolipids in the gut and its relation to inflammation and cancer. Progress in Lipid Research, 48, 62-72 (2009).

16) Ohnishi, M. and Fujino, Y., Sphingolipids in immature and mature soybean. Lipids, 17, 803-810 (1982).

17) Ohnishi, M., Ito, S. and Fujino, Y., Characterization of sphingolipids in spinach leaves. Biochim. Biophys. Acta, 752 416-422 (1982).

18) Sugawara, T., Kinoshita, M., Ohnishi, M., Nagata, J. and Saito, M., Digestion of maize sphingolipids in rats and uptake of sphingadienine by Caco-2 cells. J. Nutr., 133, 2777-2782 (2003)

19) Cua, A.B., Wilhelm, K.P. and Maibach, H.I., Elastic properties of human skin : relation to age, sex, and anatomical region. Arch. Dermatol. Res., 282, 283-288 (1990).
20) Takema, Y., Yorimoto, Y., Kawai, M. and Imokawa, G., Agerelated changes in the elastic properties and thickness of human facial skin. Br. J. Dermatol., 131, 641-648 (1994).

21）梶山葉子, 食品原料としてのコラーゲンの機能と応用, フ レグランスジャーナル，25, 58-64 (1997).

22）速水耕介, 寺山貴子, 梶原伸子, コラーゲンペプチド含有飲 料の健常者に打ける皮膚粘弾性への影響, 新薬と臨床， 49, 867-873 (2000).

23）大原浩樹, 伊藤恭子, 飯田博之, 松本 均, コラーゲンペプ チド経口摂取による皮膚角質水分量の改善効果，日本食品 科学工学会誌, 56, 137-145 (2009).

24） Hori, M., Kishimoto, S., Tezuka, Y., Nishigori, H., Nomoto, K., Hamada, U. and Yonei, Y., Double-blind study of effect of glucosylceramide in beet extract on skin elasticity and fibronectin production in human dermal fibroblasts. Anti Aging Medicine, 7, 129-142 (2010).

\section{引用 URL}

i ) http://www.maff.go.jp/j/tokei/ (2012.10.15)

(平成 24 年 11 月 15 日受付，平成 25 年 1 月 28 日受理) 